\title{
PENGGUNAAN METODE FORWARD CHAINING DALAM MENDIAGNOSA PENYAKIT PADA KALKUN
}

\author{
Corie Mei Hellyana ${ }^{1}$, Ina Maryani ${ }^{2}$, Eva Argarini Pratama ${ }^{3}$ \\ Sistem Informasi, Universitas Bina Sarana Informatika ${ }^{1,3}$ \\ Sistem Informasi, STMIK Nusa Mandiri ${ }^{2}$ \\ corie.cma@bsi.ac.id ${ }^{1}$, ina.maryani@nusamandiri.ac.id ${ }^{2}$, eva.eap@bsi.ac.id ${ }^{3}$
}

\begin{abstract}
Abstrak - Kalkun merupakan sejenis unggas yang memiliki ukuran lebih besar yang berasal dari ordo Galliformes, genus Meleagris bukanlah hewan asli Indonesia. Dikarenakan kalkun mempunyai nilai jual tinggi terutama dagingnya yang berprotein tinggi dan rendah lemak serta kolesterol, maka kalkun mulai dibudidayakan di Indonesia. Banyak peternak kalkun menganggap bahwa penyakit yang menyerang kalkun sama dengan hewan unggas yang lain, hal ini yang menyebabkan tingkat pendapatan peternak menjadi berkurang/merosot. Dengan semakin majunya perkembangan teknologi, banyak aplikasi yang sudah diterapkan untuk dapat menyelesaikan suatu masalah salah satunya dengan menggunakaan. Sistem pakar dibuat untuk dapat menyelesaikan masalah tanpa harus mendatangkan ahli/pakarnya. Dalam penelitian ini, digunakan metode forward chaining (runtut maju) dimana proses dimulai dari pencarian premis atau data masukan yang berupa gejala sehingga didapat kesimpulan penyakit pada kalkun serta memberikan solusi mengenai pencegahan dan pengobatan berdasarkan gejala-gejala yang telah teramati. Jenis penyakit yang akan didiagnosis sebanyak 10 penyakit dengan jumlah gejala penyakit sebanyak 14 gejala.
\end{abstract}

Kata kunci : penyakit kalkun, sistem pakar, forward chaining

\begin{abstract}
Turkey is a type of bird that has a larger size that comes from the order Galliformes, the genus Meleagris is not native to Indonesia. Because turkey has a high selling value, especially highprotein and low-fat meat and cholesterol, turkeys are cultivated in Indonesia. Many turkey breeders consider that diseases that attack turkeys are the same as other poultry animals, which causes the farmer's income levels to decrease/decline. With the increasingly advanced development of technology, many applications have been implemented to solve a problem, one of them is by using it. Expert systems are made to solve problems without having to bring in experts/experts. In this study, a forward chaining method was used in which the process starts from the search for premise or input data in the form of symptoms so that conclusions can be reached on turkeys and provide solutions for prevention and treatment based on observed symptoms. The types of diseases that will be diagnosed are 10 diseases with 14 symptoms of the disease.
\end{abstract}

\section{Keywords: turkey, expert system, forward chaining}

\section{PENDAHULUAN}

Kalkun, jenis unggas yang mulai dibudidayakan oleh para peternak unggas di Indonesia. Bera sal dari ordo Galliformes, genus Meleagris kalkun bukanlah jenis unggas asli Indonesia, namun kalkun mampu bertahan di suhu dan iklim Indonesia. Pada awalnya, kalkun merupakan hewan unggas yang dipelihara karena merupakan jenis hewan hias, namun pada akhir-akhir ini banyak yang mencari daging kalkun untuk dikonsumsi karena ternyata daging kalkun memiliki protein yang lebih tinggi dan rendah lemak dan kolesterol (Oktviana, 2016).

Sebagai salah sau hewan unggas, Kalkun termasuk dalam hewan yang lebih suka bergerak bebas atau dengan sistem umbaran
(Indra, 2019). Bagi peternak kalkun, untuk dapat memanen kalkun memerlukan waktu kurang lebih dua bulan untuk melihat hasil panennya (daging dan telur). Selain itu bulu kalkun juga laku dijual untuk keperluan hiasan dan aksesoris. Hal yang perlu diperhatikan para peternak kalkun dalam pembudidayaan kalkun adalah dari sisi kesehatan. Hal ini dikarenakan kalkun bukan hewan asli Indonesia dan satu hal yang menjadi momok bagi para peternak kalkun adalah minimnya pengetahuan mengenai penyakit dan cara penanganan serta pencegahan penyakit kalkun yang sakit. Meskipun kalkun tergolong dalam jenis unggas, namun dalam hal perawatan dan penanganan penyakit yang diderita kalkun berbeda dengan unggas yang 
lain sehingga dapat membuat rugi peternak kalkun.

Oleh karena itu seiring dengan kemajuan teknologi yang sangat cepat, sudah banyak teknologi yang digunakan untuk dapat membantu memecahkan suatu masalah, salah satunya adalah dengan menggunakan sistem pakar. Dengan menggunakan sistem pakar, berbagai masalah dapat dipecahkan tanpa harus mendatangkan ahlinya. Sistem pakar dibuat ini bukan berarti menggantikan dokter tetapi hanya membantu memecahkan masalah.

\section{KAJIAN PUSTAKA}

\section{A. Kalkun}

Hewan kalkun merupakan salah satu hewan yang berasal dari spesies burung dengan ukuran yang besar dari ordo Galliformes genus Meleagris. Untuk membedakan kalkun betina dan kalkun jantan, bisa dilihat dari ukurannya yaitu kalkun betina lebih kecil dan warna bulu yang kurang berwarna-warni. Rentang sayap kalkun pada saat di alam bebas bisa mencapai 1,5-1,8 meter.

Jenis kalkun dari spesies $M$. gallopavo yang atau kalkun liar (Wild Turkey) yang mulai diternakkan untuk diambil dagingnya. Sedangkan spesies $M$. ocellata adalah hasil domestikasi suku Maya yang tidak memiliki pial dan lebih gesit di alam bebas serta pandai terbang. Postur besar yang dimiliki kalkun tidak menjamin kesehatan dari kalkun tersebut. Seperti halnya dengan unggas lainnya, ayam kalkun juga bisa terkena berbagai macam penyakit. Beberapa penyakit yang menyerang kalkun antara lain:(Hasti, 2018):

\section{Cacar}

Penyakit jenis ini disebabkan oleh virus familia poxviridae dan genus Azipoxvirus. Ciri-ciri kalkun yang terserang penyakit cacar yaitu terdapat bercak-bercak merah dibadan. Usaha untuk penyembuhan dan pencegahan dapat dilakukan dengan cara pemberian vaksin dari dokter hewan.

\section{Tungau}

Ciri-ciri kalkun yang terserang penyakit tungau antara lain gelisah, sering mematuk dan mengibas bulu, nafsu makan turun, pucat dan kurus. Penyakit tungau ini disebabkan karena adanya bakteri didalam kandang yang kotor. Untuk mengatasi penyakit ini, kalkun yang sudah terserang tungau harus dipishkan dari kalkun yang sehat, kemudian kondisi kandang kalkun juga harus selalu bersih dan kering.

Untuk kalkun yang sering mengibaskan bulu karena gatal dapat diberikan larutan karbonat servin yang kemudian ditambah dengan air dan disemprotkan ke bulu/tubuh kalkun.

\section{Lumpuh}

Kalkun yang mengalami kelumpuhan dapat disebabkan karena pemberian pakan yang berlebihan. Pakan yang berlebihan dapat menyebabkkan obesitas, biasanya dialami oleh kalkun yang masih muda. Hal ini dikarenakan bahwa kalkun yng masih muuuda memiliki tulang yng belum kuat dalam menopang tubuh/berat badannya.

Selain disebabkan karena pakan berlebih, kelumpuhn pada kalkun bisa dikarenakan kalkun memakan daun pepaya dalam jumlah yang banyak. Kalkun yang mengalami kelumpuhan jari-jarinya akan membengkok ke arah dalam. Untuk mencegah hal tersebut, kalkun yang masih muda hendaknya tidak diberi pakan daun pepaya terlebih dahulu. Pemberian pakan daun pepaya dapat diberikan saat kalkun berumur 6 bulan keatas.

4. Hidung berlendir

Penyakit hidung berlendir biasanya menyerang kalkun yang kondisi kandangnya dalam keadaan lembab. Hidung berlendir yang menyerang kalkun dapat juga disebut Infectious Bronchitis (IB). Ciri-ciri kalkun yang mengalami penyakit hidung berlendir antara lain hidung kelur lendir, nafas berbau, sayap menggantung, nafsu makan menurun. Kalkun yang sudah mengalami gejala penyakit ini, sebaiknya dipisahkan dengan kalkun yang yang sehat dan kemudian diberikan obat Tetra Chlor.

5. Kolera

Penyakit kolera yang menyerang kalkun ditandai dengan pial yang membengkak. Kalkun yang sudah terkena penyakit kolera, sebaiknya segera diberikan antibiotik, misalnya Streptomycin atau Tetrasiklin.

6. Infectous Coryza

Penyakit Infectious Coryza disebut juga penyakit influenza, yang disebabkan oleh bakteri. Kalkun yang terkena infectous 
coryza harus segera dipisahkan dengan kalkun yang sehat. Yang perlu diperhatikaan agar kalkun lain tidak terjangkit peyakit ini adalah tidaak mencampur kalkun yang berbeda umur, kandang dan lingkungan dalam keadaan bersih dan harus terkena sinar matahari.

\section{B. Sistem Pakar}

Sistem pakar merupakan salah satu cabang dari Artificial Intelegent (Al) yang membuat ekstensi untuk spesialisasi pengetahuan guna memecahkan suatu masalah. Kecerdasan buatan merupakan cabang sistem informasi yang berhubungan dengan pengungkapan, pemodelan, dan penyimpanan kecerdasan manusia dalam sebuah sistem teknologi informasi sehingga sistem tersebut memiliki kecerdasan seperti yang dimiliki manusia (Rohajawati \& Supriyati, n.d.). Sistem pakar mengadopsi pengetahuan manusia ke komputer agar komputer mampu meyelesaikan masalah seperti halnya yang dilakukan oleh para ahli (Ima Apriliya, 2017).

Menurut Kusrini dalam (Ramanda, 2015), adapun ciri-ciri sistem pakar antara lain:

1. Terbatas dalam bidang yang spesifik

2. Dapat memberikan penalaran untuk data-data yang tidak lengkap atau tidak pasti

3. Dapat mengemukakan rangkaian alasan yang diberikannya dengan cara yang dapat dipahami

4. Berdasarkan pada rule atau kaidah tertentu

5. Dirancang untuk dapat dikembangkan secara bertahap

6. Outputnya bersifat nasihat atau anjuran

7. Output tergantung dari dialog dengan user

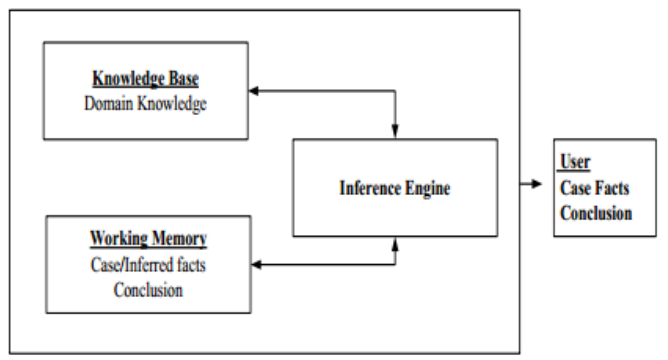

Gambar 1. Komponen Sistem Pakar

Komponen utama yang terdapat pada struktur sistem pakar meliputi Basis Pengetahuan / Knowledge Base, Mesin
Inferensi / Inference Engine, Working Memory, dan Antarmuka Pemakai / User Interface (Ramanda, 2015).

\section{Forward Chaining}

Forward chaining merupakan grup dari multiple inferensi yang melakukan pencarian dari suatu masalah kepada solusinya. Mekanisme pelacakan dimulai dari informasi masukan dan selanjutnya mencoba menggambarkan kesimpulan.

Menurut (Tinaliah, 2015), teknik pencarian dimulai dengan fakta yang diketahui, kemudian mencocokkan faktafakta tersebut dengan bagian IF dari rule IF-THEN. Bila ada fakta yang cocok dengan bagian IF, maka rule tersebut dieksekusi. Bila sebuah rule dieksekusi, maka sebuah fakta baru (bagian THEN) ditambahkan dalam database. Proses eksekusi forward chaining dapat dilihat pada gambar dibawah:

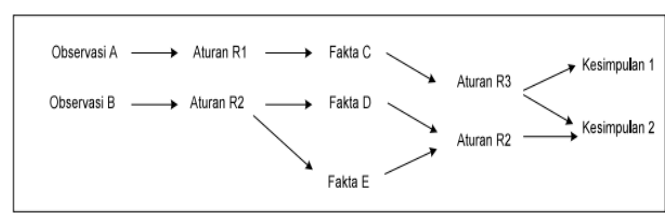

Gambar 2. Mekanisme forward chaining

Langkah - langkah dalam membuat sistem pakar dengan menggunakan metode forward chaining yaitu:

a. Pendefenisan masalah dimulai dengan pemilihan domain masalah dan akuisi pengetahuan

b. Pendefenesian data input untuk memulai inferensi karena diperlukan oleh sistem forward chaining.

c. Pendefenisian struktur pengendalian data untuk membantu mengendalikan pengaktifan suatu aturan.

d. Penulisan kode awal dalam domain pengatahuan

e. Pengujian sistem agar dapat mengatahui sejauh mana sistem berjalan

f. Perancangan antarmuka dengan basis pengatahuan

g. Pengembangan sistem

h. Evaluasi sistem 


\section{KERANGKA PIKIR}

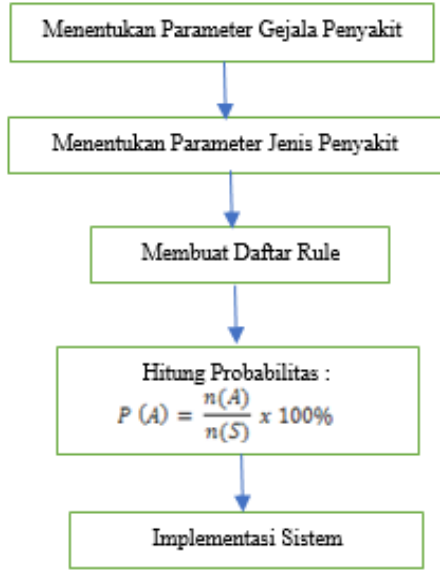

Gambar 3. Kerangka Pikir

\section{PENELITIAN TERKAIT}

\begin{tabular}{|c|c|c|}
\hline Peneliti & Judul & Hasil \\
\hline $\begin{array}{l}\text { Kresna } \\
\text { Ramanda } \\
\text { (Ramanda, } \\
\text { 2015) }\end{array}$ & $\begin{array}{l}\text { Penerapan } \\
\text { Sistem Pakar } \\
\text { Untuk } \\
\text { Mendiagnosa } \\
\text { Penyakit } \\
\text { Pada } \\
\text { Kehamilan }\end{array}$ & $\begin{array}{l}\text { - Aplikasi sistem } \\
\text { pakar dalam } \\
\text { bidang } \\
\text { kedokteran } \\
\text { yang dibuat } \\
\text { mampu } \\
\text { mengenali } \\
\text { jenis penyakit } \\
\text { pada manusia, } \\
\text { terutama jenis } \\
\text { penyakit } \\
\text { kehamilan. } \\
\text { - Aplikasi sistem } \\
\text { pakar dapat } \\
\text { menjadi sarana } \\
\text { untuk } \\
\text { menyimpan } \\
\text { pengetahuan } \\
\text { tentang } \\
\text { penyakit } \\
\text { penyakit } \\
\text { terutama yang } \\
\text { berkenaan } \\
\text { dengan jenis } \\
\text { penyakit } \\
\text { kehamilan dari } \\
\text { pakar atau } \\
\text { ahlinya. }\end{array}$ \\
\hline $\begin{array}{l}\text { Fida Wiji } \\
\text { Lestari } \\
\text { (Lestari, } \\
\text { 2017) }\end{array}$ & $\begin{array}{l}\text { Sistem Pakar } \\
\text { Penentuan } \\
\text { Jenis } \\
\text { Penyakit } \\
\text { Ayam } \\
\text { dengan } \\
\text { Metode } \\
\text { Forward } \\
\text { Chaining } \\
\text { Berbasis } \\
\text { Android }\end{array}$ & 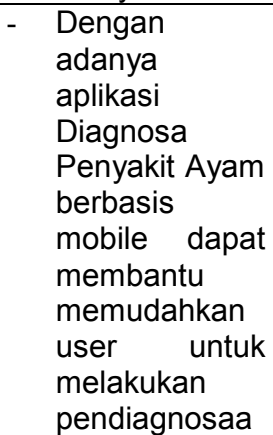 \\
\hline
\end{tabular}

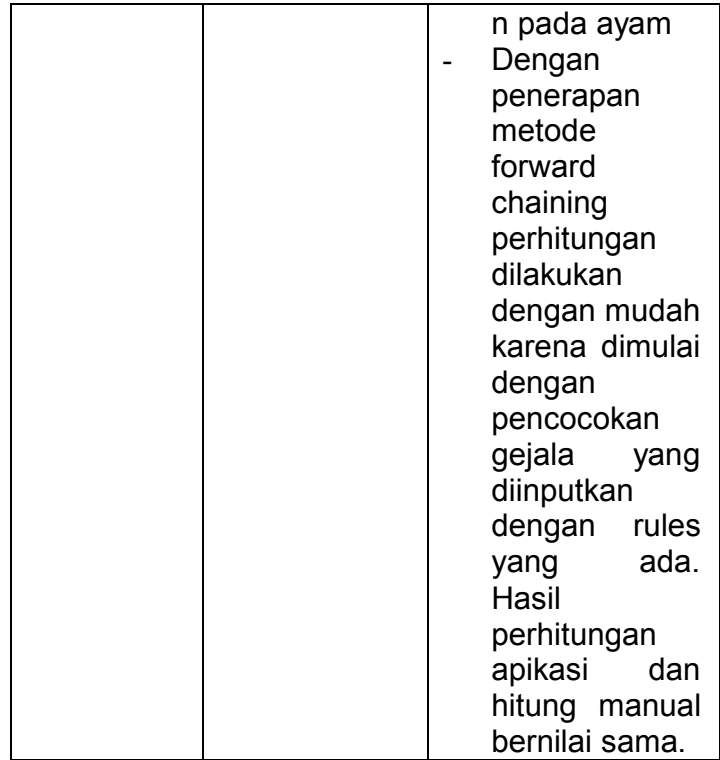

\section{PERANCANGAN SISTEM PAKAR}

Sistem pakar yang akan dibangun dan akan digunakan untuk mendiagnosis penyakit pada kalkun menggunakan metode forward chaining. Dimana metode ini bekerja dengan mencocokkan gejala-gejala yang diimplementasikan dengan pertanyaan dan akan dijawab sesuai dengan rule yang telah ada, yang kemudian didapat sebuah kesimpulan. Aturan yang diperoleh dari kumpulan fakta-fakta yang ada dan merupakan suatu gejala dari suatu penyakit tertentu yang selanjutnya dimasukkan kedalam aturan IF-THEN. Hasil keluaran yang didapat berupa nama penyakit, pengobatan dan pencegahan.

Tabel 1 dibawah menunjukkan nama penyakit beserta kode penyakit yang akan dijadikan acuan dalam membuat sistem pakar. Sedangkan pada tabel 2 akan ditunjukkan dengan kode gejala penyakit dan kemunculannya yang akan dijadikan acuan dalam membuat sistem pakar. Berdasarkan data yang terdapat tabel 1 dan tabel 2 diatas, akan dibuat tabel kemunculan gejala penyakit yang ditunjukkan pada tabel 3 . Untuk tabel 4 menunjukkan aturan yang dipakai dalam proses inferensi metode forward chaining. 
Tabel 1.Tabel Kode Penyakit dan Jenis Penyakit Pada Kalkun

\begin{tabular}{|c|c|}
\hline Kode & Jenis Penyakit \\
\hline P01 & Cacar \\
\hline P02 & Hidung Berlendir \\
\hline P03 & Kolera \\
\hline P04 & Histomoniasis \\
\hline P05 & Lumpuh \\
\hline P06 & Infectious Coryza \\
\hline P07 & Tuberkulosis \\
\hline P08 & Strepkokosis \\
\hline P09 & Tungau \\
\hline P10 & Infeksi Pseudomonas \\
\hline
\end{tabular}

Tabel 2. Tabel Kode Gejala Penyakit dan Kemunculan Gejala Pada Kalkun

\begin{tabular}{|c|c|}
\hline ID Gejala & Nama Gejala \\
\hline G01 & Wajah Pucat \\
\hline G02 & Nafsu Makan Turun \\
\hline G03 & Hidung Berlendir \\
\hline G04 & Kotoran Kuning \\
\hline G05 & Lumpuh/Tidak Bisa Berdiri \\
\hline G06 & Tulang Kaki Bengkok \\
\hline G07 & Bintil Kutil di Kepala \\
\hline G08 & Nafas Ngorok \\
\hline G09 & Jari Kaki Menekuk \\
\hline G10 & Mering Mengibas Bulu Tubuh Sendiri \\
\hline G11 & Batuk \\
\hline G12 & Mati Mendadak \\
\hline G13 & Kalkun Terlihat Gelisah \\
\hline G14
\end{tabular}

\begin{tabular}{|c|c|}
\hline $\begin{array}{c}\text { Tabel 3. } \\
\text { Tabel } \\
\text { yakit }\end{array}$ & Gejala \\
\hline P01 & $\mathrm{G} 01, \mathrm{G} 02,07$ \\
\hline $\mathrm{P} 02$ & $\mathrm{G} 01, \mathrm{G} 02, \mathrm{G} 03, \mathrm{G} 12$ \\
\hline $\mathrm{P} 03$ & $\mathrm{G} 01, \mathrm{G} 03, \mathrm{G} 08$ \\
\hline $\mathrm{P} 04$ & $\mathrm{G} 03, \mathrm{G} 07$ \\
\hline $\mathrm{P} 05$ & $\mathrm{G} 01, \mathrm{G} 05, \mathrm{G} 06, \mathrm{G} 09$ \\
\hline $\mathrm{P} 06$ & $\mathrm{G} 01, \mathrm{G} 02, \mathrm{G} 08, \mathrm{G} 12$ \\
\hline $\mathrm{P} 07$ & $\mathrm{G} 01, \mathrm{G} 02, \mathrm{G} 03, \mathrm{G} 04, \mathrm{G} 08, \mathrm{G} 12$ \\
\hline $\mathrm{P} 08$ & $\mathrm{G} 01, \mathrm{G} 02, \mathrm{G} 08, \mathrm{G} 10, \mathrm{G} 12$ \\
\hline $\mathrm{P} 09$ & $\mathrm{G} 11, \mathrm{G} 12, \mathrm{G} 14$ \\
\hline $\mathrm{P} 10$ & $\mathrm{G} 01, \mathrm{G} 02, \mathrm{G} 03, \mathrm{G} 04, \mathrm{G} 08, \mathrm{G} 12$, \\
& $\mathrm{G} 13$ \\
\hline
\end{tabular}

Tabel 4. Daftar Rule

\begin{tabular}{|c|l|}
\hline $\begin{array}{c}\text { Rule } \\
\text { ke- }\end{array}$ & \multicolumn{1}{|c|}{ Rule } \\
\hline 1 & $\begin{array}{l}\text { IF wajah pucat AND nafsu makan turun } \\
\text { AND bintil kutil di kepala THEN Cacar }\end{array}$ \\
\hline 2 & $\begin{array}{l}\text { IF wajah pucat AND nafsu makan turun } \\
\text { AND hidung berlendir AND batuk THEN } \\
\text { Hidung Berlendir }\end{array}$ \\
\hline 3 & $\begin{array}{l}\text { IF wajah pucat AND hidung berlendir AND } \\
\text { nafas ngorok THEN Kolera }\end{array}$ \\
\hline 4 & $\begin{array}{l}\text { IF hidung berlendir AND bintil kutil di } \\
\text { kepala THEN Histomoniasis }\end{array}$ \\
\hline 5 & $\begin{array}{l}\text { IF wajah pucat AND lumpuh/tidak bisa } \\
\text { berdiri AND tulang kaki bengkok AND jari } \\
\text { kaki menekuk THEN Lumpuh }\end{array}$ \\
\hline 6 & $\begin{array}{l}\text { IF wajah pucat AND nafsu makan turun } \\
\text { AND nafas ngorok AND batuk THEN } \\
\text { Infectious Coryza }\end{array}$ \\
\hline 7 & $\begin{array}{l}\text { IF wajah pucat AND nafsu makan turun } \\
\text { AND hidung berlendir AND kotoran kuning } \\
\text { AND nafas ngorok AND batuk THEN } \\
\text { Tuberkulosis }\end{array}$ \\
\hline 8 & $\begin{array}{l}\text { IF wajah pucat AND nafsu makan turun } \\
\text { AND nafas ngorok AND sering mengibas } \\
\text { bulu AND batuk THEN Strepkokosis }\end{array}$ \\
\hline 9 & $\begin{array}{l}\text { IF mematuk tubuh sendiri AND batuk AND } \\
\text { kalkun terlihat gelisah THEN Tungau }\end{array}$ \\
\hline 10 & $\begin{array}{l}\text { IF wajah pucat AND nafsu makan turun } \\
\text { AND hidung berlendir AND kotoran kuning } \\
\text { AND nafas ngorok AND batuk AND mati } \\
\text { mendadak THEN Infeksi Pseudomonas }\end{array}$ \\
\hline
\end{tabular}

\section{HASIL PENGUJIAN METODE}

Pengujian metode forward chaining untuk mendeteksi penyakit pada kalkun dilakukan untuk 10 jenis penyakit yang ditunjukkan pada tabel 1 diatas. Pada pengujian metode ini, semua pertanyaan akan diuji dan setiap model pertanyaan akan mewakili pengujian dari rule 1 sampai 10. Setelah semua pengujian pertanyaan dilakukan, maka akan dilakukan perhitungan prosentase keberhasilan dari metode forward chaining.

Misal terdapat gejala berikut: G03, G06, G05, G10, G08 mesin inferensi akan melakukan pencocokan gejala diatas dengan rule keputusan seperti berikut:

$$
\begin{aligned}
& \mathrm{G} 03 \rightarrow \mathrm{P} 02, \mathrm{P} 03, \mathrm{P} 07, \mathrm{P} 10 \\
& \mathrm{G} 06 \rightarrow \mathrm{P} 05 \\
& \mathrm{G} 12 \rightarrow \mathrm{P} 02, \mathrm{P} 06, \mathrm{P} 07, \mathrm{P} 08, \mathrm{P} 09, \mathrm{P} 10 \\
& \mathrm{G} 10 \rightarrow \mathrm{P} 08 \\
& \mathrm{G} 08 \rightarrow \mathrm{P} 03, \mathrm{P} 06, \mathrm{P} 07, \mathrm{P} 08, \mathrm{P} 10
\end{aligned}
$$




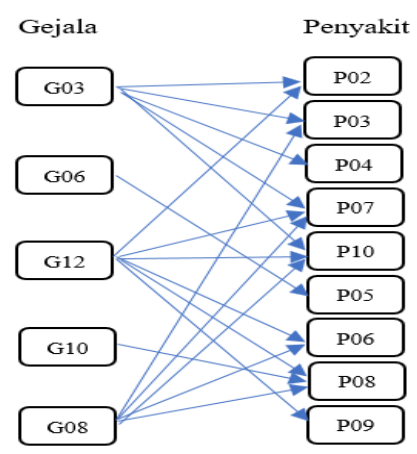

Berdasarkan hasil mesin inferensi diatas, ditemukan beberapa penyakit yang kemungkinan diderita oleh kalkun dengan gejala seperti yang telah diinputkan yaitu P02, P03, P04, P07, P10, P05, P06, P08, P09. Untuk dapat memastikan penyakit yang diderita oleh kalkun, maka kemungkinan nilai yang paling besar harus dihitung berdasarkan rumus dibawah ini yang nantinya akan diperoleh prosentase dari masing-masing penyakit.

$$
P(A)=\frac{n(A)}{n(S)} \times 100 \%
$$

Keterangan :

$P(A)=$ Nilai Kemungkinan

$\mathrm{n}(\mathrm{A})=$ Banyak gejala yang terdeteksi pada penyakit tertentu

$\mathrm{n}(\mathrm{S})=$ Jumlah total gejala yang dimiliki penyakit tertentu

Hasil perhitungan inferensi diatas sebagai berikut:

1. Untuk P02 memiliki $n(A)=1, n(S)=4$, maka $P=1 / 4 \times 100 \%=25 \%$

2. Untuk P03 memiliki $n(A)=1, n(S)=3$, maka $P=1 / 3 \times 100 \%=33,33 \%$

3. Untuk P07 memiliki $n(A)=1, n(S)=6$, maka $P=1 / 6 \times 100 \%=16,67 \%$

4. Untuk P04 memiliki $n(A)=1, n(S)=2$, maka $P=1 / 2 \times 100 \%=50 \%$

5. Untuk P10 memiliki $\mathrm{n}(\mathrm{A})=1, \mathrm{n}(\mathrm{S})=7$, maka $P=1 / 7 \times 100 \%=14,28 \%$

6. Untuk P05 memiliki $\mathrm{n}(\mathrm{A})=1, \mathrm{n}(\mathrm{S})=4$, maka $P=1 / 4 \times 100 \%=25 \%$

7. Untuk P06 memiliki $n(A)=1, n(S)=4$, maka $P=1 / 4 \times 100 \%=25 \%$

8. Untuk P08 memiliki $\mathrm{n}(\mathrm{A})=1, \mathrm{n}(\mathrm{S})=5$, maka $P=1 / 5 \times 100 \%=20 \%$

9. Untuk P09 memiliki $n(A)=1, n(S)=3$, maka $P=1 / 3 \times 100 \%=33,33 \%$

Berdasarkan perhitungan mesin inferensi diatas, ditemukan diagnosa penyakit yang diderita berdasarkan gejala yang diinput yaitu P02, P03, P04, P07, P10, P05, P06, P08, P09. Kemungkinan terbesar dari gejala yang telah diinput, kalkun menderita penyakit P04
(Histimoniasis) karena memiliki nilai kemungkinan $50 \%$.

\section{IMPLEMENTASI SISTEM}

Pada penerapan aplikasi penulis menggunakan platform android dengan pertimbangan mudah untuk digunakan. Pada aplikasi ini mempunyai bebera tampilan antara lain:

\section{Halaman Menu Utama}

Pada halaman menu utama akan ditampilkan beberapa menu yaitu Beranda, Data Penyakit Konsultasi dan Keluar. Tampilannya dapat dilihat di Gambar 7.1 sebagai berikut:

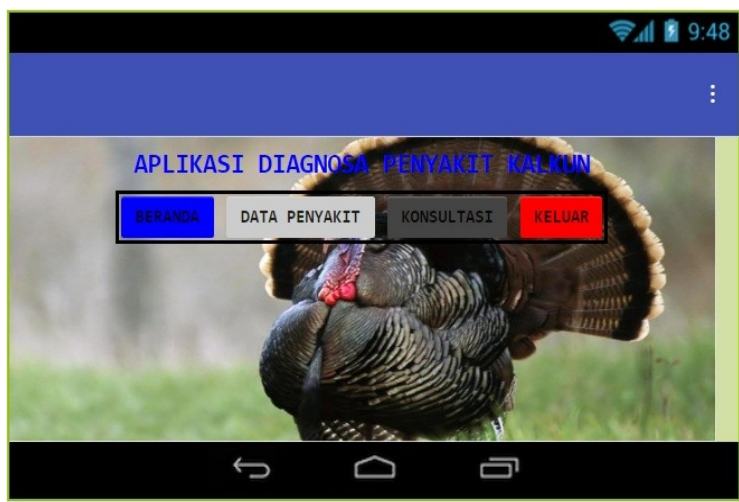

Gambar 4. Halaman Menu Utama Aplikasi

\section{Halaman Data Penyakit}

Pada halaman ini menampilkan jenis penyakit yang ada pada kalkun. Ketika pengguna memilih salah satu dari beberapa jenis penyakit yang ada maka akan muncul penjelasan tentang sebab penyakit dan solusinya.

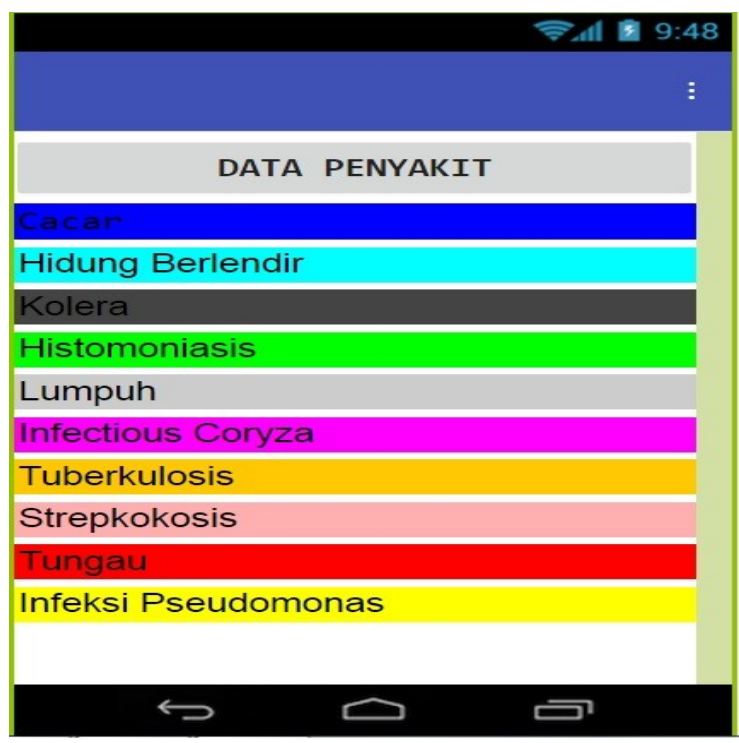

Gambar 5. Halaman Data Penyakit 


\section{Halaman Konsultasi}

Pada halaman ini user atau pengguna dapat berkonsultasi dengan cara menjawab beberapa pertanyaan terkait kondisi Kalkun.

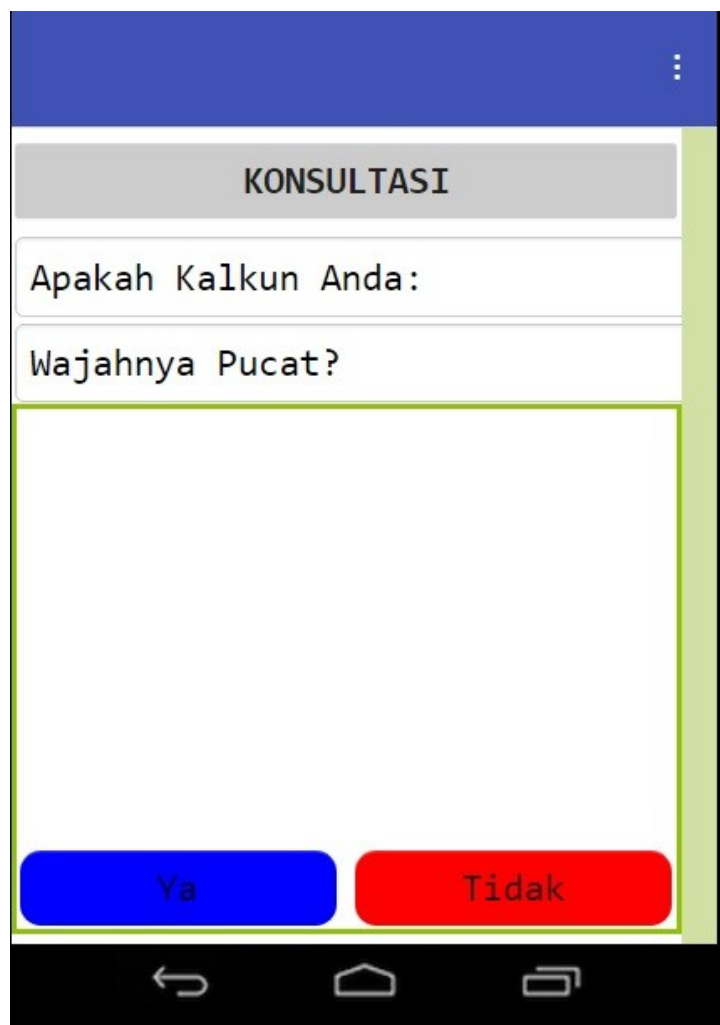

Gambar 6. Pertanyaan Gejala Penyakit 1

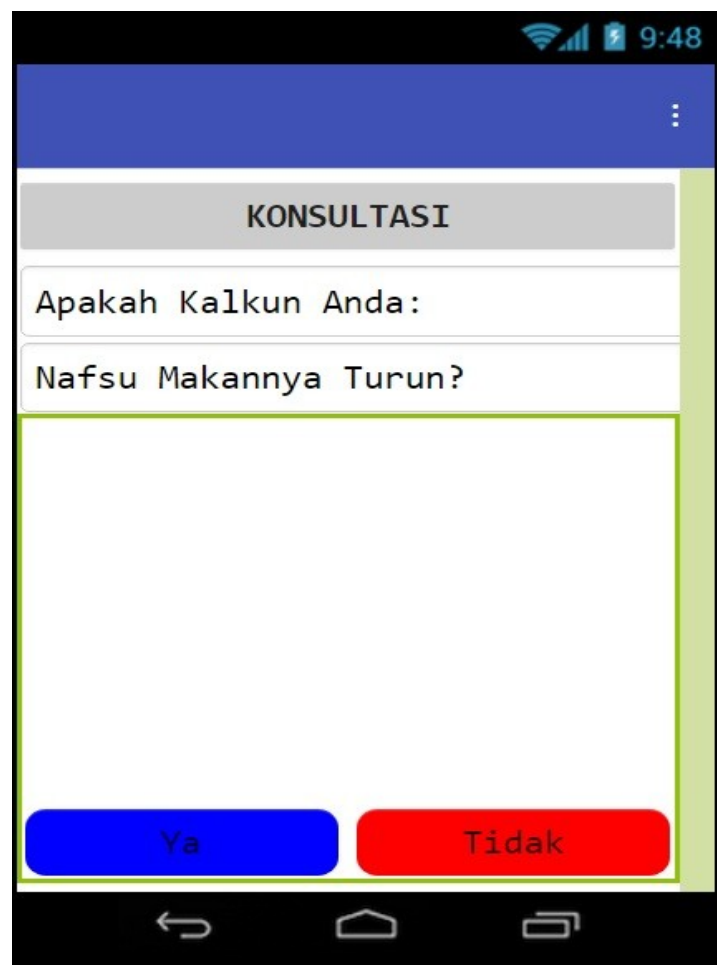

Gambar 7. Pertanyaan Gejala Penyakit 2



Gambar 8. Pertanyaan Gejala Penyakit 2

\section{Halaman Solusi}

Setelah Pengguna menjawab pertanyaan mengenai gejala penyakit yang menyerang Kalkun kemudian aplikasi akan menampilkan halaman solusi yang berisi solusi pengobatannya.

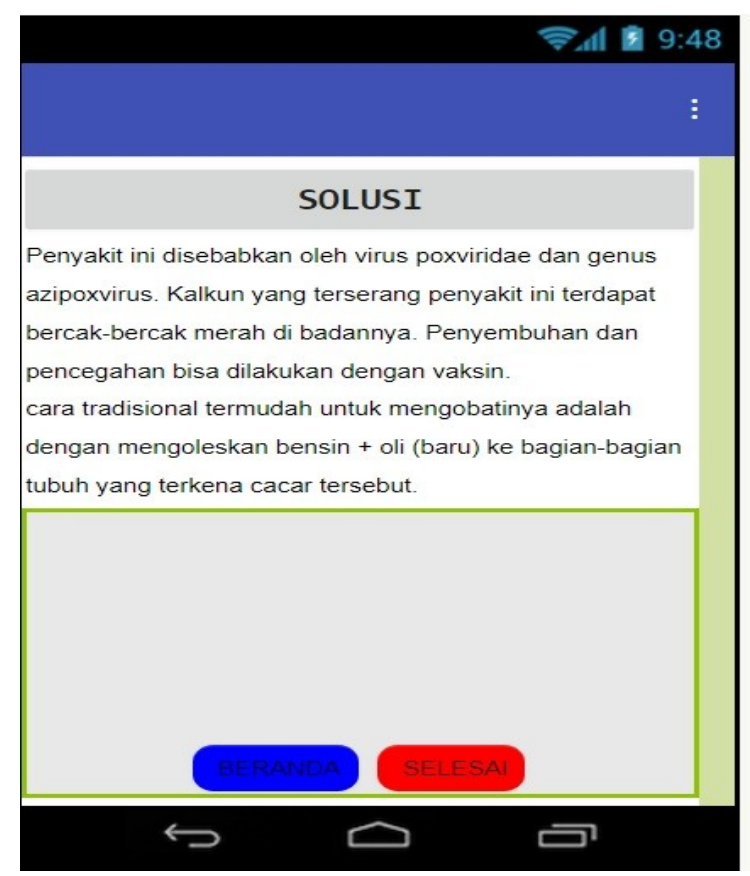

Gambar 9. Gambar Solusi 


\section{PENUTUP}

Berdasarkaan penelitiann yang telah dilakukan, penelitian ini menghasilkan sistem diagnosa penyakit pada kalkun. Proses dimulai dari Menentukan Parameter Gejala Penyakit kemudian menentukan parameter jenis penyakit selanjutnya membat daftar rule dan melakukan perhitungan probabilitas. Untuk gejala penyakit sebanyak 14 gejala dan untuk jenis penyakit dibutuhkan data penyakit sebanyak 10. Proses pengujian dilakukan dengan menggunakan metode Forward Chaining. Selanjutnya Peneliti mengimplementasikannya pada sebuah aplikasi sistem pakar diagnosa penyakit Kalkun berbasis android untuk memudahkan pengguna, karena user dapat mengetahui penyakit yang menyerang Kalkun dan pengobatannya secara online tanpa harus menemui dokter/pakar pada saat itu juga.

Pada penelitian selanjutnya bisa dilakukan uji coba dengan menggunakan metode lainnya dan dikembangkan jenis penyakit serta gejalanya.

\section{DAFTAR PUSTAKA}

Hasti. (2018). Penyakit yang Menyerang Ayam Kalkun dan Cara Mengatasinya. Retrieved from https://hobiternak.com/penyakit-ayamkalkun-cara-mengatasinya/

Ima Apriliya, I. W. (2017). Sistem Diagnosis Penyakit pada Kambing Menggunakan Metode Forward Chaining. Jurnal IImiah Teknologi InformasiAsia, 11(2), 113-122.

Indra. (2019). 17 Cara Ternak Ayam Kalkun Mudah Menguntungkan. Retrieved from https://arenahewan.com/cara-ternakayam-kalkun

Lestari, F. W. (2017). Sistem Pakar Penentuan Jenis Penyakit Ayam dengan Metode Forward Chaining Berbasis Android. Journal of Information and Technology, 05 nomor O(June), 93-103.

Oktviana, E. dkk. (2016). JIIA, VOLUME 4 No. 3 AGUSTUS 2016. JIIA, 4(3), 262-268.

Ramanda, K. (2015). Penerapan sistem pakar untuk mendiagnosa penyakit pada kehamilan. Pilar Nusa Mandiri, XI(2), 179-185.

Rohajawati, S., \& Supriyati, R. (n.d.). SISTEM PAKAR: DIAGNOSIS PENYAKIT UNGGAS DENGAN METODE CERTAINTY FACTOR Penyakit Ayam, 41-46.

Tinaliah. (2015). Aplikasi sistem pakar untuk diagnosa penyakit hewan ternak sapi dengan. Jurnal IImiah SISFOTENIKA, 5(1), 13-24. 